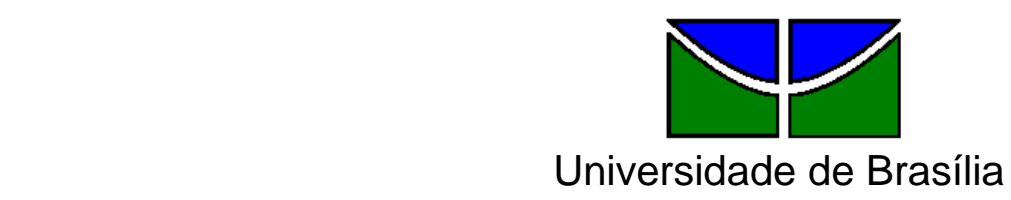

Faculdade de Economia, Administração, Contabilidade e Ciências da Informação e Documentação

\author{
EULLER DE SÁ BARROS
}

\title{
AS VIVÊNCIAS DE PRAZER E SOFRIMENTO NO TRABALHO DE DISTRIBUIÇÃO DE BEBIDAS
}

\author{
Brasília - DF \\ Dezembro / 2009
}


Universidade de Brasília

Faculdade de Economia, Administração, Contabilidade e Ciências da Informação e Documentação

\section{AS VIVÊNCIAS DE PRAZER E SOFRIMENTO NO TRABALHO DE DISTRIBUIÇÃO DE BEBIDAS}

Projeto apresentado ao Departamento de Administração como requisito parcial à obtenção do título de Bacharel em Administração.

Professor Orientador: Doutor, Marcus Vinicius Siqueira

Brasília - DF

Dezembro / 2009 
Barros, Euller de Sá.

As Vivências De Prazer E Sofrimento No Trabalho De Distribuição De Bebidas/ Euller de Sá Barros. - Brasília, 2009.

47 f. : il.

Monografia (bacharelado) - Universidade de Brasília, Departamento de Administração, 2009.

Orientador: Prof. Doutor Marcus Vinícius Siqueira, Departamento de Administração.

1. prazer-sofrimento no trabalho 2. estratégias defensivas 3 . organização do trabalho 


\title{
AS VIVÊNCIAS DE PRAZER E SOFRIMENTO NO TRABALHO DE DISTRIBUIÇÃO DE BEBIDAS
}

A Comissão Examinadora, abaixo identificada, aprova o Trabalho de Conclusão do Curso de Administração da Universidade de Brasília do (a) aluno (a)

\section{Euller de Sá Barros}

\author{
Doutor, Marcus Vinicius Siqueira \\ Professor-Orientador \\ Especialista, Maria de Fátima Bruno \\ Professor-Examinador \\ Doutor, Pedro Meneses \\ Professor-Examinador
}


Agradeço à Nay pela colaboração com as inúmeras revisões, pelas dicas e, sobretudo, por estar ao meu lado sempre que precisei.

Agradeço também aos meus pais pelo apoio e pela cobrança constante, ambos foram muito úteis. 


\section{RESUMO}

Este trabalho teve como objetivo identificar e analisar vivências de prazer e sofrimento no trabalho de distribuição de bebidas. O referencial teórico é da psicodinâmica do trabalho que estuda a inter-relação trabalho e saúde. Os participantes são trabalhadores de uma empresa de distribuição que presta serviços para uma multinacional do ramo de bebidas. A metodologia do estudo contempla estratégia qualitativa para análise e coleta de dados. A coleta de dados ocorreu entre setembro a novembro de 2009, realizada por meio da técnica de entrevista semi-estruturada com questões norteadoras, cujo conteúdo foi registrado mediante uso de gravador e transcritos posteriormente. Participaram do estudo sete trabalhadores do setor de distribuição de bebidas da empresa estudada. Para analisar os dados foi utilizado o método de análise de conteúdo com respaldo teórico nas contribuições da Psicodinâmica do Trabalho. Nas entrevistas foram identificadas seis categorias analíticas, divididas em três grupos. No grupo fonte de prazer as categorias foram: "Ser amigo de todo mundo é o que mais me da prazer" e "Eu acho que sim, sou bastante reconhecido.". No grupo fontes de sofrimento as seguintes categorias estão presentes: "Tamo sempre no batidão"; "Eles querem que a gente chegue cedo, mas põem um monte de entrega" e "Todo mundo pensa que garrafeiro é ladrão.". O último grupo, Sentido e Significado do trabalho é composto pela categoria "...a pessoa sem trabalho não tem nada na vida". Com base nestas categorias, identifica-se uma organização do trabalho que exige altos níveis de produtividade dos trabalhadores. Estes utilizam da auto-aceleração como estratégia defensiva, gerando sofrimento e alienação sobre a situação em que se encontram. $O$ reconhecimento está presente e é fonte de prazer para os entrevistados. $\mathrm{O}$ trabalho é visto como fonte de sustento, mas também como fator de identidade pessoal e motivo de orgulho.

1. prazer-sofrimento no trabalho
2. estratégias

defensivas
3. organização do trabalho 


\section{LISTA DE QUADROS}

QUADRO 1 - "Ser amigo de todo mundo é o que mais me da prazer" ...................29

QUADRO 2 - "Eu acho que sim, sou bastante reconhecido." ................................30

QUADRO 3 - "Tamo sempre no batidão" ...................................................... 32

QUADRO 4 - "Eles querem que a gente chegue cedo, mas põem um monte de

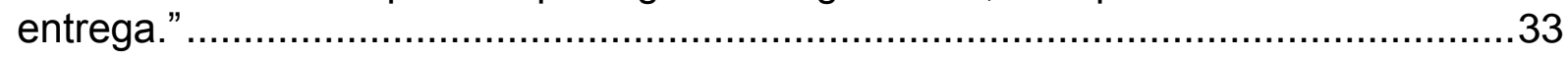

QUADRO 5 - "Todo mundo pensa que garrafeiro é ladrão." ..................................35

QUADRO 6 - “...a pessoa sem trabalho não tem nada na vida.”...........................37 


\section{SUMÁRIO}

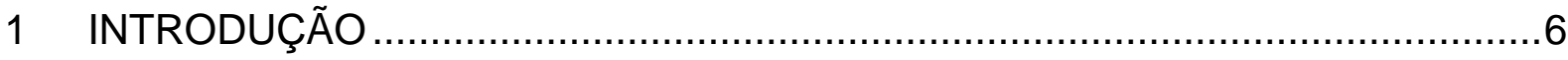

1.1 Contextualização do Assunto.....................................................

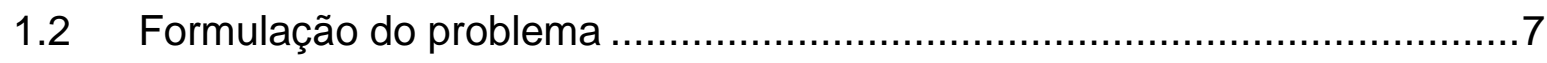

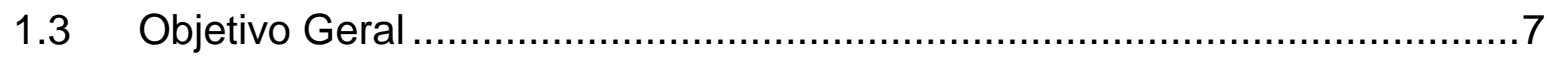

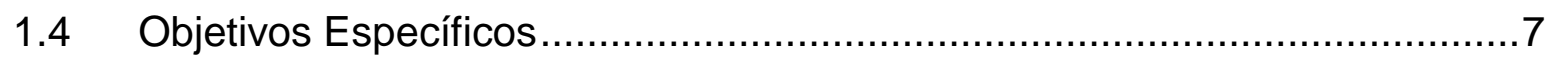

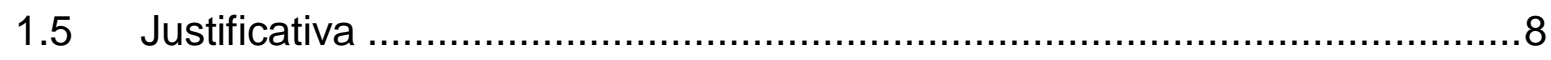

1.6 Métodos e Técnicas de Pesquisa .................................................... 8

1.7 Estrutura e Organização do Projeto .................................................

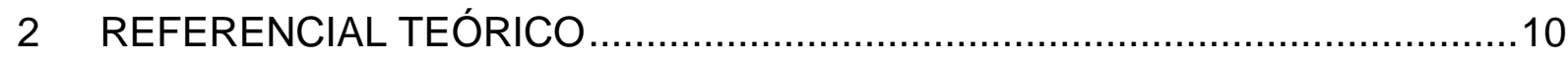

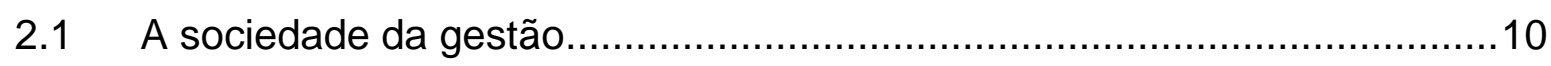

2.2 Psicodinâmica do Trabalho e a Organização do Trabalho.........................15

2.3 Prazer-Sofrimento no Trabalho e Estratégias Defensivas do Indivíduo ......18

3 MÉTODOS E TÉCNICAS DE PESQUISA .................................................23

3.1 Tipo e descrição geral da pesquisa................................................23

3.2 Caracterização da organização, setor ou área .....................................24

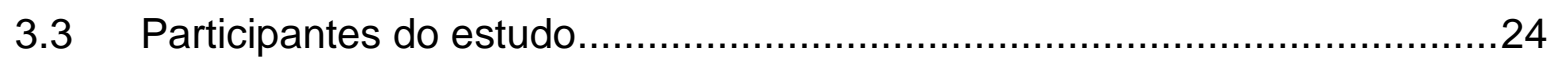

3.4 Caracterização dos instrumentos de pesquisa ...................................25

3.5 Procedimentos de coleta e de análise de dados...................................26

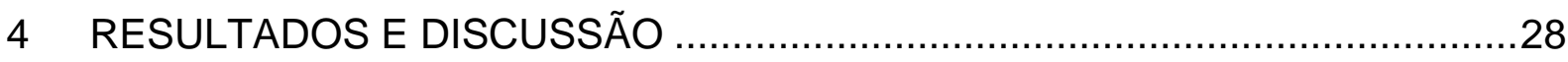

Fontes de Prazer...................................................................... 28

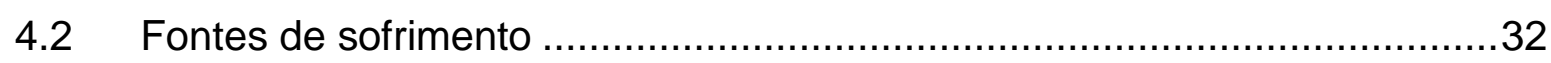

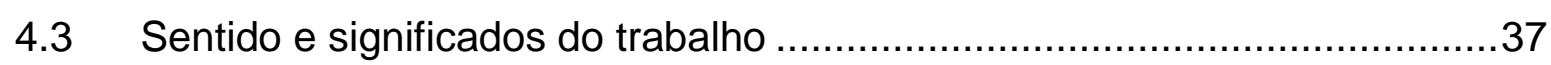

5 CONCLUSÃO E RECOMENDAÇÕES ..................................................4 40

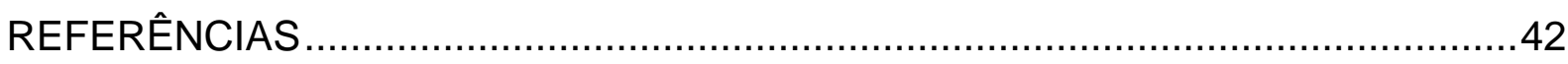

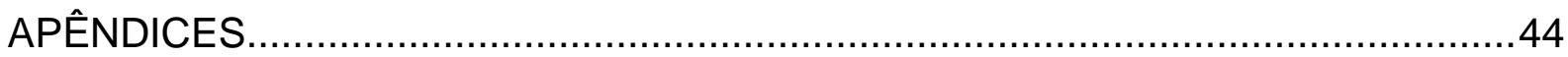




\section{INTRODUÇÃO}

A introdução deste estudo está dividida em sete partes. Primeiramente, é feito o detalhamento do contexto em que o trabalho está inserido, com apresentação de um breve histórico sobre o tema psicodinâmica do trabalho e seu objeto de estudo.

Em seguida, são apresentados o problema de pesquisa formulado, o objetivo geral, os objetivos específicos determinados para o trabalho e a justificativa para o estudo.

Posteriormente é descrita a metodologia de pesquisa escolhida, e por fim é feito um resumo do conteúdo das demais partes do trabalho.

\subsection{Contextualização do Assunto}

O presente estudo se encaixa dentro da temática da psicodinâmica do trabalho, proposta por Dejours (1987). Os primeiros estudos sobre vivências de prazer e sofrimento no trabalho foram realizados no início dos anos 1980 na França. Apenas no início dos anos 1990 foram feitas as primeiras pesquisas sobre o tema no Brasil. O tema vem ganhando relevância no contexto acadêmico nacional, sendo Brasília um dos pólos de pesquisa, graças ao GEPSAT - Grupo de Estudos e Pesquisas em Saúde e Trabalho, da Universidade de Brasília (UnB).

O eixo de análise do estudo é a temática de trabalho, prazer e sofrimento, baseada no estudo da psicodinâmica do trabalho, que articula a organização do trabalho e os processos de subjetivação manifestos nas vivências de prazersofrimento e nas estratégias de ação para mediar contradições. 


\subsection{Formulação do problema}

As vivências de prazer e sofrimento no ambiente de trabalho são aspectos relevantes para a compreensão plena da situação do trabalhador e para a busca pela melhora em sua produtividade e eficiência aliadas ao seu bem-estar. Essas vivências são bastante intensas no setor de distribuição de bebidas, marcado pela pressão por resultados e pelo cumprimento de prazos, além do esforço físico envolvido no desempenho das tarefas cotidianas. A despeito desses aspectos, os estudos dessa temática no setor de distribuição são quase inexistentes.

Neste contexto, é patente identificar quais são as vivências de prazersofrimento de trabalhadores do setor de distribuição de bebidas.

\subsection{Objetivo Geral}

Analisar vivências de prazer e sofrimento no trabalho de distribuição de bebidas.

\subsection{Objetivos Específicos}

Descrever as características da organização do trabalho no setor de distribuição de bebidas;

Identificar a construção de estratégias utilizadas pelos trabalhadores para a busca do prazer e para o enfrentamento do sofrimento no trabalho de distribuição;

Identificar a visão de trabalhadores do setor de distribuição de bebidas dos sentidos do trabalho;

Levantar a visão dos trabalhadores sobre a dinâmica de reconhecimento no trabalho. 


\subsection{Justificativa}

A globalização, a disseminação das tecnologias e a crescente automação dos meios de produção têm gerado ganhos significativos em termo de produtividade e de desenvolvimento econômico para as empresas. Contudo, tais benefícios têm sido obtidos à custa do capital humano.

O trabalhador passou a ser considerado um fator dentro da empresa e a maioria dos estudos realizados sobre as organizações tem como objetivo aumentar o desempenho da organização e não a busca por entender como as novas formas de organização do trabalho impactam o indivíduo-trabalhador.

O trabalho passou a representar um papel importante para os indivíduos, pois representa muitas vezes o local de concretização da sua própria identidade. Nesse sentido, é importante garantir que o trabalho seja gerador de prazer para o trabalhador e não um mecanismo de sofrimento e adoecimento.

Identificar como a organização do trabalho afeta os trabalhadores, quais vivências de prazer e sofrimento esse indivíduo vive no ambiente de trabalho e entender como ele reage a esse sofrimento é imprescindível para a busca de uma gestão mais humana.

A ausência de estudos relacionados às vivências de prazer e sofrimento com trabalhadores do setor de distribuição no Brasil reforça a importância de se estudar esse tema.

\subsection{Métodos e Técnicas de Pesquisa}

Para atender ao objetivo geral e aos objetivos específicos da pesquisa, foi realizada uma pesquisa de caráter qualitativo, através da realização de entrevistas semi-estruturadas com oito trabalhadores do setor de distribuição de bebidas funcionários de uma empresa nacional atuante na área de logística e distribuição. 


\subsection{Estrutura e Organização do Projeto}

O referencial teórico, capítulo 2 deste projeto, está dividido em três partes para melhor compreensão dos temas tratados. Na primeira parte será analisado o contexto sócio-organizacional em que o estudo está inserido. Será apresentada a evolução dos mecanismos de gestão e do papel das empresas na sociedade, bem como o seu poder sobre os indivíduos.

Em seguida será apresentado o objeto de estudo da psicodinâmica do trabalho e sua evolução histórica. A definição de organização do trabalho e o impacto desta sobre o indivíduo também serão discutidos no texto.

A última parte do referencial irá tratar sobre as vivências de prazer e sofrimento no trabalho, apresentando definições, conceitos e as condições que podem gerar o prazer ou o sofrimento no trabalho. Também será definido o conceito de estratégias de defesa, sendo citados exemplos da utilização dessas estratégias para o enfrentamento do sofrimento no trabalho.

O capítulo 3 irá apresentar a metodologia utilizada, explicando a sua categorização e apresentando a base teórica utilizada para desenvolvê-la.

Os resultados das entrevistas realizadas e as discussões sobre estes resultados estão apresentados no capítulo 4. O capítulo apresenta as fontes de prazer e de sofrimento identificadas através da análise das falas dos participantes e também apresenta o sentido e o significado do trabalho para os trabalhadores.

A conclusão do trabalho é encontrada no capítulo 5. O capítulo apresenta as limitações do estudo realizado e sinaliza recomendações para pesquisas futuras. 


\section{REFERENCIAL TEÓRICO}

O referencial teórico foi dividido em três partes para facilitar a apresentação dos temas. A primeira parte trata das organizações e seu papel na sociedade, a segunda discorre sobre a psicodinâmica do trabalho e a organização do trabalho e por último são apresentados os conceitos de prazer e sofrimento no trabalho, bem como as estratégias de defesa.

\subsection{A sociedade da gestão}

A busca pela compreensão das organizações e de seu impacto no indivíduo torna necessário o entendimento das reais motivações da gestão, além da compreensão e do papel que ela ocupa na sociedade.

Para compreender as organizações, é preciso considerar o espaço social em uma época específica, ou seja, o contexto sócio-histórico na qual estão inseridas (FREITAS, 2000). Nesse sentido, para entender as organizações contemporâneas, é necessário ter em conta que o século $X X$ foi caracterizado por rápidas transformações econômicas, sociais e culturais, além do intenso desenvolvimento tecnológico. Além disso, nesse período pode ser observado o aumento do poder relativo das empresas, que passaram, em grande medida, a guiar os rumos da economia e da vida social, produzindo novos tipos de relações de trabalho e estilos de vida (SIQUEIRA, 2009).

Em meados do século $X X$, o modelo de gestão predominante era o modelo fordista de produção, que buscava conciliar a exigência de lucro demandada pelos acionistas, as necessidades dos clientes e a melhoria das condições de trabalho. A partir da década de 1980, o movimento de internacionalização e de financiarização da economia transformou esse contexto, alterando as relações entre capital e trabalho (GAULEJAC, 2007).

A mudança da lógica da produção para a lógica financeira gerou a ascensão da chamada gestão dos recursos humanos, onde o efetivo passou a ser considerado como um custo que precisava ser reduzido e flexibilizado ao máximo (GAULEJAC, 
2007). Segundo Stigliz (2003), a flexibilidade organizacional é como uma "senha para dizer salários mais baixos e menor segurança no emprego". (SIQUEIRA, 2009, p.31)

Nas últimas décadas do século $X X$ o mundo passou a viver um novo contexto em termos empresariais e de gestão, com a ascensão da automação nas fábricas. $O$ cliente passa a ser colocado no centro das atenções e o processo de satisfação do cliente acontece em um ambiente altamente competitivo (SIQUEIRA, 2009).

Para Gaulejac (2007), a globalização opõe o capital e o trabalho, em desfavor do último. Se para Taylor o aumento do lucro deveria vir acompanhado do aumento dos salários, para os gestores contemporâneos as "exigências do mercado" justificam práticas como o deslocamento de unidades produtivas para países que possuem uma legislação menos favorável para os empregados. O "gerenciamento" (do francês, management) passa a ser utilizado a serviço do capital, em detrimento do trabalhador.

No contexto da globalização, o poder das multinacionais tem se tornado cada vez maior e mais presente na sociedade moderna. Algumas empresas, devido ao seu poder econômico, exercem influências em decisões políticas, direta ou indiretamente, através de contribuições para campanhas políticas e de lobby junto a governistas (SIQUEIRA, 2009).

As mudanças pelas quais a gestão organizacional passou nos últimos anos foram pautadas por um conjunto de crenças que deram base não apenas às construções teóricas acerca da gestão, mas também à formulação de práticas organizacionais que garantissem a manutenção da relação de poder do capital sobre o trabalho. Dentre essas crenças, as mais notórias são as ciências de gestão e a ideologia gerencialista. Definida como "um sistema de pensamento que se apresenta como racional, ao passo que mantém uma ilusão e dissimula um projeto de dominação (...) de um sistema econômico que legitima o lucro como finalidade" (GAULEJAC, 2007, p.65), a ideologia gerencialista, assim como as ciências da gestão, são sustentadas por paradigmas comuns, construídos ao longo do século XX. Esses paradigmas são, segundo Gaulejac (2007), os seguintes:

- Objetivista: A visão objetivista das organizações tem como princípio básico compreender a organização através de variáveis e parâmetros que possam ser medidos, eliminando todas as variáveis não mensuráveis. 0 homo economicus é tido como a representação do indivíduo, onde todos 
os registros afetivos, emocionais, imaginários são considerados como nãoconfiáveis.

- Funcionalista: A teoria funcionalista procura ligar os fenômenos sociais às funções que eles garantem. Sob esta ótica, o paradigma funcionalista busca analisar a organização como um sistema cuja finalidade é garantir sua reprodução.

- Experimental: Este paradigma considera o trabalhador como um dado científico, que deverá ser objeto de observação para o desenvolvimento de técnicas que irão melhorar sua produtividade e seu rendimento.

- Utilitarista: O paradigma utilitarista prega que cada ator busca "maximizar suas utilidades". Nesse sentido a reflexão só é bem-vista quando serve para melhorar o desempenho da organização, sendo posta a serviço da ação.

- Economista: Este paradigma considera o humano um fator/recurso da empresa, gerando uma instrumentalização do indivíduo. Colocando o desenvolvimento da empresa como um fim em si mesmo, o paradigma economista ignora a necessidade do desenvolvimento da empresa também contribuir para o desenvolvimento da sociedade.

O pensamento estritamente econômico da ideologia gerencialista e os paradigmas que a sustenta reforçam a propagação de discursos que buscam diminuir o peso da proteção social, criticam o salário mínimo, alegando o quanto ele onera as empresas, e tentam abolir direitos trabalhistas, colocando a regulamentação do trabalho como um obstáculo para o desenvolvimento econômico (GAULEJAC, 2007).

Outra conseqüência do desenvolvimento do capitalismo financeiro é a despersonalização e desterritorialização das fontes do poder. Enquanto no início do século o capital estava concentrado nas mãos de algumas poucas famílias, hoje ele se encontra difundido entre "investidores institucionais". Essa configuração faz com que o lugar em que ocorre a atividade de produção não seja necessariamente o mesmo no qual ocorre a tomada de decisão (GAULEJAC, 2007).

Em meio a essas mudanças o indivíduo passou a ser considerado um fator de produção, sendo visto como um ativo que está subordinado ao capital. Sob esta ótica as empresas esperam que o trabalhador deve se adaptar às constantes 
mudanças estabelecidas pelo capital, como a flexibilização organizacional e a multifuncionalidade na execução das tarefas (SIQUEIRA, 2009).

As mudanças nas fontes do poder também geraram mudanças na forma como o poder se apresenta nas organizações. Do nascimento do capitalismo até meados do século $X X$, as organizações estavam organizadas de forma piramidal, pautadas por normas disciplinares. Diferentemente das organizações industriais tradicionais, regidas pelo poder disciplinar, as organizações hipermodernas são organizadas sob um poder gerencialista que, ao contrário do poder disciplinar proposto por Foucalt (1997), é aparentemente menos repressivo. De acordo com Gaulejac (2007) o poder gerencialista não se preocupa em promover a transformação da energia libidinal em força de trabalho, tampouco busca controlar os corpos. Ele busca a exaltação do desejo, no lugar da canalização das necessidades. Para substituir a repressão, são utilizados mecanismos de sedução, de adesão e de obediência, inspirada pela necessidade de reconhecimento por parte do indivíduo.

Neste sentido, o poder gerencialista é apresentado como uma evolução em relação ao caráter opressivo e estático do sistema disciplinar. O trabalho, sob essa ótica, é tido como uma experiência interessante, enriquecedora e estimulante, onde o trabalhador deve se sentir responsável pelos resultados e estar motivado a preencher seus objetivos com entusiasmo e determinação. Para que se alcance esse fim, o desejo é constantemente exaltado, seja através da ambição pelo sucesso, do gosto pelo desafio, da necessidade de reconhecimento ou da recompensa pelo mérito pessoal. A empresa se torna o lugar da realização de si mesmo (GAULEJAC, 2007). No novo contexto a empresa passa a representar para o indivíduo um lugar para alcançar seus objetivos, mesmo que em detrimento da sua identidade própria (SIQUEIRA, 2009).

Nas organizações modernas os jogos de poder nem sempre são representados por uma imposição do dominador sobre o dominado. Por um lado o indivíduo é objeto de dominação através de controles sutis como a internalização de valores e o a exaltação do desejo, por outro lado ele pode igualar forças com 0 dominador por meio da criação de grupos de resistência às decisões organizacionais ou da abdicação do empenho em alcançar os objetivos organizacionais (SIQUEIRA, 2009). 
A vigilância nas empresas hipermodernas não consiste mais apenas no controle do indivíduo e de suas ações. O foco do monitoramento recai sobre os resultados, e não apenas sobre as ações dos funcionários. Essa mudança dá maior liberdade de atuação para os trabalhadores e, por outro lado, gera uma intensa pressão sobre o alcance dos resultados (GAULEJAC, 2007).

$A$ crescente exigência de resultados imposta pela organização fez com que os horários de trabalho fixos deixassem de ser suficientes para responder a essas exigências. Com isso, a fronteira entre o tempo de trabalho e o tempo fora do trabalho foi se tornando menos nítida. O surgimento de novas tecnologias, como os notebooks e celulares, contribuíram para promover ligações além da fronteira entre 0 profissional e o privado, o trabalho e o afetivo. O indivíduo passou a estar disponível não apenas durante o horário de trabalho, mas de forma permanente e livre. (GAULEJAC, 2007)

A disponibilidade do indivíduo mesmo fora do horário de trabalho é o reflexo da dominação que toma conta do inconsciente do indivíduo. $O$ trabalhador percebe a organização como parte essencial de sua existência e batalhará pelo sucesso da empresa. Ao mesmo tempo em que deseja se livrar da dominação do mundo organizacional, o indivíduo não pretende se desligar da empresa e dos benefícios que ela Ihe proporciona (SIQUEIRA, 2009).

A força da gestão gerencialista encontra-se em um sistema de valores que favorece o engajamento individual onde a busca pelo lucro está atrelada a um ideal. A empresa propõe um ideal comum que deverá se tornar o ideal de todos os empregados. Para isso, é preciso que os valores individuais não sejam contraditórios com os valores da organização. Esse alinhamento é garantido inicialmente através do processo de seleção e, posteriormente, por processos de formação internos, dispositivos de avaliação, procedimentos de promoção e outras ferramentas (GAULEJAC, 2007).

O modelo hierárquico de organização possuía uma relação clara entre trabalhador e empresa, que definia que o funcionário deveria trabalhar por um número de horas no escritório ou na fábrica e em troca disso seria remunerado. No modelo gerencialista, por sua vez, a empresa propõe ao indivíduo a satisfação de seus desejos de sucesso e o coloca em uma dependência psíquica em relação à organização. (GAULEJAC, 2007) 
A substituição das normas disciplinares pelo modelo do poder gerencialista submeteu o indivíduo a uma injunção paradoxal, em que o indivíduo se encontra frente a uma ordem impossível de ser obedecida. Neste sentido, sua simples obediência acarreta infração. Quanto mais o indivíduo se identifica com a empresa, mais ele perde sua própria autonomia. Quanto mais a empresa progride, mais o indivíduo regride (GAULEJAC, 2007).

Para Gaulejac (2007) o poder que as empresas exercem tem como pilar de sua força três mecanismos que canalizam a ação a serviço do capitalismo. $O$ primeiro é o álibi da guerra econômica. Ele consiste em fazer acreditar na vulnerabilidade da empresa, cuja sobrevivência estaria ameaçada, justificando a necessidade de se realizar sacrifícios para salvá-la. O segundo mecanismo de poder é a individualização e a dissolução dos coletivos que poderiam defender os trabalhadores. Nesse caso, os indivíduos são incentivados a se preocuparem mais com a carreira individual do que com uma reflexão de conjunto ou com ações para defender interesses do pessoal. O terceiro mecanismo consiste na utilização das injunções paradoxais para inibir a razão e favorecer a aceitação da racionalidade instrumental. Para se defender contra a pressão do trabalho, o empregado se envolve totalmente na atividade, não pensando em lutar contra a angústia gerada pelo sistema. Gaulejac conclui afirmando que o poder gestionário, através dos mecanismos apresentados, neutraliza definitivamente a violência do capitalismo, despolitizando o poder dentro da empresa e ocultando a relação de dominação presente no seio da organização (GAULEJAC, 2007).

$O$ atual contexto social e econômico exerce enorme influência sobre a organização do trabalho e, conseqüentemente, sobre os trabalhadores, gerando impacto nas vivências e sentimentos destes. Para compreender essa influência é preciso entender como se dá a psicodinâmica do trabalho e a sua relação com a organização do trabalho.

\subsection{Psicodinâmica do Trabalho e a Organização do Trabalho}

A Teoria da Psicodinâmica do Trabalho, proposta por Christophe Dejours (1987), tem por finalidade analisar como a dinâmica do ambiente de trabalho afeta a 
população que trabalha e como estes reagem às implicações da organização do trabalho, permanecendo saudáveis. Segundo Mendes (2007, p. 30) a psicodinâmica tem como objeto de estudo "as relações dinâmicas entre organização do trabalho e processos de subjetivação". A psicodinâmica estuda também como se manifestam as vivências de prazer-sofrimento dos trabalhadores, quais estratégias de ação estes utilizam para lidar com as contradições da organização do trabalho e como a organização do trabalho causa patologias sociais, afeta a saúde e provoca o adoecimento (MENDES, 2007).

A evolução da psicodinâmica é marcada por três fases. A primeira está associada ao seu surgimento, na década de 1980, sob a denominação de psicopatologia do trabalho. Nesta fase, a psicodinâmica estava focada no estudo do sofrimento do sujeito-trabalhador, ocasionado por condições de trabalho precárias e pela organização do trabalho inspirada no modelo taylorista de produção. A segunda fase, ocorrida em meados da década de 1990, é caracterizada pelo enfoque nas vivências de prazer-sofrimento inerentes ao contexto de trabalho e na análise das estratégias usadas pelos trabalhadores para manter a própria saúde, evitando o adoecimento e ainda assegurando a produtividade. Na terceira fase, que se inicia no final da década de 1990 e segue até hoje, a psicodinâmica se consolida como abordagem científica capaz de explicar a relação entre o trabalho e os processos de subjetivação, as patologias sociopsíquicas e a saúde dos trabalhadores. Atualmente, o foco da psicodinâmica não está mais nas vivências de prazer-sofrimento por si mesmas, mas na subjetivação dessas experiências pelos trabalhadores, e na identificação do sentido que elas assumem para os trabalhadores (MENDES, 2007).

O estudo da psicodinâmica do trabalho está ligado à análise da organização do trabalho, pois, como afirma Mendes (1999, p. 22) "a organização do trabalho exerce influências multideterminadas no funcionamento psíquico dos trabalhadores". Os elementos da organização do trabalho variam de acordo com o setor em que organização atua. Suas influências no trabalhador podem ser positivas ou negativas, variando de acordo com o confronto entre as características de personalidade e a margem de liberdade admitida pelo modelo de organização vigente (MENDES, 1999).

O conceito de organização do trabalho é designado por Dejours (1987, p.25) "a divisão do trabalho, o conteúdo da tarefa, o sistema hierárquico, as modalidades de comando, as relações de poder, as questões de responsabilidade". 
A origem da palavra organização, derivada do grego orgamon, remete a ferramenta ou instrumento. A organização do trabalho de forma mecanizada, com uma intensa especialização de tarefas e procedimentos, teve origem no militarismo e evoluiu ao longo dos anos até chegar ao modelo de administração científica proposto por Taylor no início do século XX. Tal modelo ofereceu a base para o modo de trabalhar por toda a primeira metade do século $X X$ e está presente em muitas organizações até os dias de hoje (MORGAN, 2007).

A restrição do espaço de liberdade promovida pelo modelo taylorista de produção transforma o trabalhador em objeto e não em sujeito da produção. Os mecanismos de produção vigentes favoreciam a racionalização, o controle hierárquico e a divisão entre o trabalho normal e o intelectual (MARTINS, 2002).

Segundo Mendes (1999), os princípios do modelo taylorista de produção dificultam ao trabalhador ter uma visão integrada do que faz, uma vez que o trabalho se torna automatizado, repetitivo e monótono, o que pode gerar uma sensação de que seu trabalho não tem sentido e significado.

Os trabalhadores produzem algo através da realização de tarefas, ou seja, de procedimentos, instrumentos ou modos operatórios com a finalidade de atingir um objetivo. A forma como o trabalho é organizado irá determinar se as tarefas realizadas possuem, ou não, conteúdos significativos (MENDES, 1999).

Nesse sentido, o conteúdo significativo da tarefa em relação ao sujeito representa o grau de satisfação que o trabalho assume em termos de evolução pessoal, aperfeiçoamento e status social do posto de trabalho que ele ocupa, além de representar os investimentos simbólicos que o sujeito destina à tarefa (DEJOURS, 1987).

A organização do trabalho de baseada na administração científica de Taylor tem gerado um enorme aumento de produtividade ao longo dos anos. Porém, por melhor que seja a definição da organização do trabalho, nenhuma organização pode evitar a discrepância entre organização do trabalho prescrita e a organização do trabalho real. A organização real do trabalho diverge da organização prescrita, pois é impossível prever antecipadamente todas as variáveis do trabalho. Se todos os trabalhadores de uma empresa seguissem à risca as instruções que the são transmitidas, não haveria produção. Esse mecanismo já foi utilizado em algumas situações por operários revoltosos e é conhecido como "operação padrão", do francês grève du zèle (DEJOURS, 1999). 
Observa-se que o processo de trabalho só funciona quando os trabalhadores melhoram a organização do trabalho através da mobilização de suas inteligências, individual e coletivamente. Dejours (1999) coloca que o motor dessa inteligência seria o medo, originado da constante ameaça de demissão. $O$ trabalhador com medo se mostra capaz de acionar um vasto conjunto de artifícios criativos para melhorar a produção e assim diminuir suas chances de ser demitido (DEJOURS, 1999).

Tais modelos de produção, que enfocam o controle do processo de trabalho e promovem a não qualificação dos trabalhadores, vêm sendo questionados. surgimento de novos paradigmas técnico-econômicos tem possibilitado a ascensão de organizações do trabalho em que a tarefa é enriquecida com certo grau de responsabilidade, favorecendo a ampliação do campo de ação do trabalhador. Esses novos modelos de organização do trabalho ainda são considerados de transição, mas demonstram a existência de alternativas para a organização do trabalho (MENDES, 1999).

Considerando as colocações feitas sobre a organização do trabalho, o conteúdo da tarefa e as divergências entre o trabalho real e o trabalho prescrito fica exposto que o trabalho pode fazer emergir nos trabalhadores vivências psicológicas tanto de prazer quanto de sofrimento, variando de acordo com o conteúdo significativo da tarefa e das regras estabelecidas.

\subsection{Prazer-Sofrimento no Trabalho e Estratégias Defensivas do Indivíduo}

A psicodinâmica do trabalho estuda as vivências de prazer-sofrimento no trabalho como dialéticas inerentes ao contexto de trabalho. $O$ trabalho é um encontro com o sofrimento, portanto são estudadas suas origens e quais as estratégias utilizadas pelos trabalhadores para enfrentar o sofrimento e obter 0 prazer no trabalho (MENDES, 2007).

De acordo com os estudos em psicodinâmica, o sofrimento no trabalho surge quando há o bloqueio na relação do trabalhador com organização do trabalho, devido a dificuldades de negociação das diferentes forças que envolvem o desejo da produção e o desejo do trabalhador (MENDES, 2007). 
Considerando que a relação do homem com a organização do trabalho é a origem da cara psíquica do trabalho, em uma organização do trabalho autoritária, que não permite uma diminuição desta carga psíquica, o trabalho passa a ser fatigante (DEJOURS, 1994).

O sofrimento é definido por Mendes (1999) como "uma vivência de desgaste no trabalho". Esse desgaste é representado pela sensação de cansaço, desânimo e descontentamento com relação ao trabalho.

Pesquisas realizadas por Dejours (1987) demonstram que o trabalho contém vários elementos que influenciam a formação da auto-imagem do trabalhador e, por sua vez, geram o sofrimento.

O autor identifica no discurso dos trabalhadores quatro temas que indicam as situações de trabalho causadores do sofrimento. O primeiro tema diz respeito à indignidade, e se refere ao sentimento da vergonha de ser robotizado, de se tornar não mais que uma extensão da máquina e de não visualizar significação do trabalho (MENDES, 1999). O segundo tema é a vivência do sentimento de inutilidade ligada a falta de qualificação e ausência de finalidade do trabalho. O trabalhador desconhece o propósito do seu trabalho e seu trabalho não possui significação humana, ou seja, não tem significado para a família, amigos ou para o grupo social (MENDES, 1999).

Outro tema é o da desqualificação, que tem como sentido a imagem de si que é refletida pelo trabalho. Neste sentido, quanto mais complexa as tarefas realizadas, mais honroso o trabalho será considerado (MENDES, 1999).

A vivência depressiva é o quarto tema apresentado e condensa os sentimentos de indignidade, inutilidade e desqualificação, ampliando-os. O trabalhador passa a ser dominado pelo cansaço, cuja origem não se dá apenas por esforços musculares, mas resulta sobretudo do contexto em que o trabalhador está inserido. A ausência de atividades intelectuais e criativas promove o adormecimento intelectual, ocasionando a vontade de executar uma tarefa sem investimento material e afetivo (MENDES, 1999).

As relações entre o sofrimento e a organização nem sempre são pautadas pela idéia da felicidade fora do trabalho e a promessa de desprazer no interior da instituição. O trabalho também pode ser fonte de prazer e promover a saúde do trabalhador. Na luta contra o sofrimento, o trabalhador acaba por elaborar soluções que são favoráveis tanto para a produção quanto para a saúde (MARTINS, 2002). 
O prazer é definido por Mendes (1999, p.32) como "a vivência de sentimentos de valorização e reconhecimento no trabalho". O sentimento de valorização denota que o trabalho tem sentido e valor para o trabalhador e é importante e significativo para a organização e para a sociedade. O reconhecimento está ligado relacionado a aceitação e admiração no trabalho, e envolve ter liberdade para expressar sua individualidade (MENDES, 1999).

Para obter satisfação no trabalho, o processo de organização deve tornar-se flexível, permitindo ao trabalhador uma forma de empregar as aptidões psicomotoras, psicossensoriais e psíquicas, além de propiciar ao indivíduo a oportunidade de levar em conta suas habilidades na execução do trabalho (DEJOURS, 1994).

A vivência de prazer pelo trabalhador pode ser resultante da transformação do sofrimento e também pode ser um resultado direto do trabalho. A realidade de trabalho influência a construção da auto-imagem e da identidade do trabalhador, o que favorece a vivência de prazer ou a transformação do sofrimento (MENDES, 1999).

Mendes (1999, p. 40) afirma que "o sofrimento pode ser transformado em prazer a partir do reconhecimento no trabalho. Do reconhecimento depende o sentido do sofrimento para cada sujeito". Se, por um lado, o sofrimento é capaz de desestabilizar a identidade e a personalidade, por outro ele é elemento para a normalidade quando há a luta individual e coletiva contra ele. O reconhecimento, por outro lado, é fonte de realização do "eu" (MENDES, 1999).

O reconhecimento é definido por Mendes (2007, p.44) como o "processo de valorização do esforço e do sofrimento investido para realização do trabalho que possibilita ao sujeito a construção de sua identidade (...) e realização de si mesmo"

A mobilização subjetiva é um processo utilizado pelos trabalhadores para transformar situações causadoras de sofrimento através do engajamento no trabalho, lançando mão de sua inteligência prática e do coletivo de trabalho. Esse processo aconteceu a partir do resgate do sentido do trabalho - que depende da relação entre a subjetividade do trabalhador -, do saber fazer e do coletivo de trabalho (MENDES, 2007).

O prazer-sofrimento são vivências psíquicas que se manifestam de formas diferenciadas para cada indivíduo, variando de acordo com o sentido que ele atribui 
ao trabalho, com os aspectos simbólicos que constituem sua subjetividade e com a história de vida do indivíduo (MENDES, 1999).

Os trabalhadores impactados pelo sofrimento causado pela organização do trabalho fazem uso de estratégias defensivas para enfrentar o sofrimento no trabalho. Tais estratégias se aproximam, do ponto de vista teórico, dos mecanismos estudados pela psicanálise (MENDES, 1999). Mendes (1999, p.46) define essas estratégias defensivas como "mecanismos utilizados pelos trabalhadores para minimizar, evitar ou negar a realidade de trabalho que gera sofrimento". Tais estratégias defensivas podem ser agrupadas em três tipos: estratégias de proteção, de adaptação e de exploração.

As defesas de proteção são caracterizadas por modos de pensar, sentir e agir compensatórios, racionalizando as situações geradoras de sofrimento e permitindo que estas perdurem por longo período de tempo (MENDES, 2007).

As defesas de adaptação e de exploração exigem um maior investimento físico e sociopsíquico, e têm por base a negação do sofrimento e a submissão ao desejo. Essas estratégias de defesa permitem a subordinação do desejo do trabalhador ao desejo da produção (MENDES, 2007).

A racionalização, a passividade e 0 individualismo correspondem respectivamente às defesas de proteção, exploração e adaptação. A racionalização é utilizada como subterfúgio para a falha tentativa de explicar de forma lógica os motivos que causam o sofrimento. Sua manifestação ocorre através da realização de atividades fora do espaço de trabalho (MENDES, 1999).

O individualismo é utilizado frente ao sentimento de impotência que os trabalhadores sentem em relação à falta de cooperação, de confiança e de regras compartilhadas entre os diversos níveis hierárquicos (MENDES, 1999).

A estratégia da passividade admite situações de tédio, a ameaça de perder o emprego e a manutenção do status quo pela empresa, com a justificativa de que forças poderosas que cercam a empresa, ameaçando a organização e o trabalhador (MENDES, 1999).

Mendes (1999) ressalta a importância de se considerar que as defesas não são padronizadas para todas as categorias profissionais ou sequer para todas as organizações, pois elas variam de acordo com o contexto.

Conclui-se que as defesas contra o sofrimento são necessárias, porém podem gerar conseqüências negativas para a saúde mental no trabalho. Portanto, é 
reforçada a importância do papel do trabalho de oferecer espaço para o reconhecimento, a liberdade e a valorização do trabalhador, permitindo o equilíbrio psíquico (MENDES, 1999). 


\section{MÉTODOS E TÉCNICAS DE PESQUISA}

\subsection{Tipo e descrição geral da pesquisa}

Tendo em vista que o ser humano é o objeto principal de investigação deste estudo, buscou-se uma metodologia que permitisse considerar os aspectos subjetivos presentes na sua relação com o mundo do trabalho. Assim sendo, foi feita a opção de realizar este estudo segundo as perspectivas da pesquisa qualitativa, visando compreender as questões da subjetividade observadas nas falas dos indivíduos.

A pesquisa qualitativa, ao contrário da pesquisa quantitativa - que busca enumerar ou medir os eventos estudados por meio de instrumentos estatísticos para análise dos dados - busca obter dados a partir da perspectiva dos participantes utilizando o contato direto do pesquisador com o objeto de estudo (GODOY, 1995).

Godoy (1995, p. 62) afirma que "a pesquisa qualitativa tem o ambiente natural como fonte direta de dados e o pesquisador como instrumento fundamental". Nesse sentido, Mendes $(2007$, p.68) ressalta a importância da "concentração e envolvimento emocional, não colocando o sujeito da pesquisa na condição de objeto".

Considerando os objetivos da pesquisa, o estudo realizado pode ser classificado como do tipo descritivo, pois busca expor características do contexto de trabalho dos trabalhadores do setor de distribuição de bebidas, embora não explique estes problemas (VERGARA, 2005).

No que se refere aos meios de investigação, a pesquisa pode ser classificada como pesquisa de campo, conforme proposto por Vergara (2005), uma vez que foi realizada uma investigação empírica junto aos trabalhadores através da realização de entrevistas guiadas por um roteiro semi-estruturado. 


\subsection{Caracterização da organização, setor ou área}

O presente estudo foi realizado junto a uma empresa atuante na área de logística, que possui mais dez anos de mercado e está presente em oito estados. 0 estudo foi realizado com trabalhadores da Filial Brasília da organização.

A empresa estudada atende clientes nos mais diversos ramos de atividade, desde matérias primas como grãos, materiais para construção civil e pré-misturas industriais, até produtos acabados não-duráveis como alimentos e bebidas, e produtos duráveis como eletroeletrônicos e eletrodomésticos em geral.

A empresa é parte de um grupo empresarial que atua nas áreas de distribuição, transportes e armazenagem de produtos. A filial escolhida atua na distribuição urbana, garantindo a entrega ponto-a-ponto dos produtos e presta serviços para uma multinacional do ramo de bebidas.

\subsection{Participantes do estudo}

O estudo foi realizado com integrantes da equipe de distribuição da Filial Brasília da organização escolhida. O número total de trabalhadores entrevistados foi estipulado em sete. Esse número foi definido levando em consideração as limitações de tempo para realização do estudo e a dificuldade de obter trabalhadores disponíveis para a aplicação da entrevista.

Os trabalhadores que compõem a equipe de distribuição são organizados em trios, sendo cada trio composto por um motorista e dois ajudantes. Página: 24 Embora, em média, cinqüenta e cinco trios façam parte da equipe de distribuição, o número de trios costuma variar ao longo do ano.

A equipe de distribuição é formada majoritariamente por trabalhadores de baixa escolaridade, com mais de 30 anos de idade. Não há mulheres dentre os membros da equipe.

Para os objetivos do estudo não há distinção entre motoristas e ajudantes, ambos serão referidos como trabalhadores da equipe de distribuição. A distinção não é feita porque se considera que as vivências de prazer e sofrimento de ambos os cargos são similares. Também se considerou a limitação no número de 
entrevistados, que não seria suficiente para que se pudesse analisar cada cargo separadamente de forma adequada.

\subsection{Caracterização dos instrumentos de pesquisa}

O roteiro da entrevista, que se encontra no apêndice $A$, foi organizado em cinco partes. O roteiro foi baseado na proposta apresentada por Mendes (2007) tendo em vista os objetivos do presente trabalho.

A primeira parte do roteiro tem por objetivo criar um rapport com 0 entrevistado, ou seja, estabelecer um vínculo de confiança entre o pesquisador e o seu sujeito, deixando-o confortável para falar livremente (BLEGER, 1991).

A segunda parte busca investigar o contexto do trabalho, identificando as dimensões da organização e as condições e relações socioprofissionais do trabalho. Foram investigadas percepções sobre as características da atividade, ritmo, processos, controles do trabalho, práticas de $\mathrm{RH}$, relações de poder, fluxo de comunicação, interação entre pares, entre o trabalhador e a chefia e entre os clientes do serviço e o trabalhador (MENDES, 2007).

A parte seguinte tem por objetivo investigar os sentimentos no trabalho, explorando as vivências de prazer e sofrimento através da descrição por parte do trabalhador de seus sentimentos com relação ao trabalho. Foram requisitados ao entrevistado exemplos das situações em que tais sentimentos ocorrem, sua freqüência e a que características do trabalho os sentimentos estão relacionados (MENDES, 2007).

A quarta parte investiga os modos de enfrentar a organização do trabalho e visa identificar os tipos de estratégias de mediação que os trabalhadores dispõem e utilizam para enfrentar o sofrimento. Foram analisadas a utilização da inteligência prática, as defesas e a mobilização da subjetividade no engajamento no trabalho (MENDES, 2007).

A última parte se refere à análise da percepção dos trabalhadores sobre o reconhecimento pelo trabalho realizado, identificando as formas pelas quais este reconhecimento se apresenta e seu impacto sobre os trabalhadores. Também foi analisada a visão dos trabalhadores quanto ao sentido do trabalho para estes. 


\subsection{Procedimentos de coleta e de análise de dados}

A coleta de dados foi realizada por meio da técnica de entrevista semiestruturada, baseada no roteiro descrito anteriormente.

A entrevista semi-estruturada caracteriza-se pela flexibilidade que possibilita um contato mais próximo entre o entrevistador e o entrevistado e a exploração em profundidade de todos os aspectos considerados relevantes para o estudo. O seu direcionamento pode ser ampliado, considerando sempre as necessidades do projeto, ou seja, dos objetivos, pressupostos e do objeto da pesquisa (LAVILLE; DIONNE, 1999).

Considerando-se a relação entre aplicação da entrevista e objeto de estudo da psicodinâmica, Mendes (2007) define a entrevista como uma técnica para coletar dados sobre a organização do trabalho, vivências de prazer-sofrimento, processos de subjetivação e as mediações utilizadas pelos trabalhadores através da relação pesquisadores-pesquisados e do processo de fala-escuta-fala dos conteúdos manifestos e latentes.

A coleta de dados ocorreu entre outubro e novembro de 2009. Os trabalhadores da equipe de distribuição foram contatados individualmente $\mathrm{e}$ informados sobre a realização da pesquisa, os seus objetivos, bem como sobre os procedimentos para coleta de dados.

As entrevistas foram realizadas com uso do gravador, pelo próprio pesquisador, durante o horário de trabalho, conforme disponibilidade dos trabalhadores, com autorização prévia dos entrevistados.

A análise dos dados foi realizada por meio de núcleos de sentido (ANS), que se baseia na técnica de análise de conteúdo categorial desenvolvida por Bardin (1977), e permite descobrir "núcleos de sentido", cuja presença ou ausência podem compor significados para o tema estudado (MENDES, 2007).

A análise do conteúdo é proposta e definida por Bardin (1977) como um conjunto de técnicas para análise das comunicações que tem por finalidade obter indícios, por meio da descrição do conteúdo das mensagens, para a dedução de conhecimentos ligados ao contexto que originou a mensagem.

Analisar os dados por meio da técnica de análise de conteúdo significa que este procedimento deve estar baseado em uma definição precisa dos objetivos da 
pesquisa que variam em cada análise e condicionam a diferença de técnicas utilizadas (RICHARDSON, 1989).

A ANS consiste no desmembramento do texto em unidades que são constituídos por núcleos de sentido formados a partir da investigação dos temas psicológicos que se destacam no discurso (MENDES, 2007).

Num primeiro momento, foram identificados os temas recorrentes e registradas as verbalizações correspondentes. Em seguida, estes temas forma agrupados em categorias-síntese de acordo com os critérios de semelhança, lógica e pertinência dos conteúdos, com base nas dimensões da organização do trabalho, nas vivências de prazer-sofrimento no trabalho e estratégias de defesa utilizadas pelos trabalhadores. 


\section{RESULTADOS E DISCUSSÃO}

Neste capítulo serão apresentados e discutidos os resultados deste estudo de caso. Os resultados foram agrupados em núcleos de sentidos, desmembrando o texto em categorias, a partir da análise da fala dos participantes do estudo, conforme proposto por Mendes (2007). As categorias foram então agrupadas em grupos temáticos, para melhor compreensão de acordo com o tema que abordado. Os grupos temáticos são: I) Fontes de Prazer: apresentação de aspectos do trabalho que geram prazer no trabalhador; II) Fontes de Sofrimento: apresentação de aspectos do trabalho que geram sofrimento no trabalhador, III) Significado do trabalho: demonstra a percepção dos trabalhadores sobre o significado do trabalho e o papel que este representa.

Os núcleos de sentido ou categorias empíricas foram nomeados com trechos da fala dos participantes do estudo. A partir da seleção desses trechos são apresentadas a definição da categoria síntese das entrevistas, os temas encontrados na fala dos entrevistados, as verbalizações agrupadas em torno do núcleo de sentido e, por último, a discussão dos resultados encontrados.

\subsection{Fontes de Prazer}

Mendes (2007) afirma que um dos sentidos do trabalho é o prazer. O prazer no trabalho emerge quando o trabalho cria identidade. $O$ reconhecimento, a realização e a liberdade são fontes de prazer, pois permitem que o trabalhador se torne sujeito da ação e possa dominar o seu trabalho, não sendo dominado por ele.

Serão apresentadas as categorias criadas a partir da fala dos entrevistados que demonstram características da organização do trabalho que agem como fontes de prazer para os trabalhadores. 
QUADRO 1: Categoria síntese A das entrevistas individuais

\section{"Ser amigo de todo mundo é o que mais me da prazer"}

\section{Definição}

Há muitas relações de amizade no trabalho. A organização dos trabalhadores em equipes favorece a aproximação entre os indivíduos e a consolidação de amizades. As equipes são divididas em três salas, cada sala com aproximadamente 20 equipes, fato que aumenta o ambiente de interação entre os membros da equipe. A possibilidade da conversa durante o trabalho atenua o esforço físico que está sendo realizado. Os funcionários costumam trabalhar na mesma região por muitos anos o que favorece o estabelecimento de amizade também com clientes.

\section{Temas}

- Boas relações no trabalho

- Amigo de todo mundo

- Pessoa comunicativa

\section{Exemplo de verbalizações:}

- "Trabalho como profissionais, né, mas assim, são amigos também, gosta de ajudar os funcionários, e é uma relação assim muito boa, entendeu? Todo mundo gosta de ajudar todo mundo".

- "Ser amigo de todo mundo é o que mais me dá prazer. Eu chegar do trabalho e saber que fulano, beltrano e sicrano vão conversar comigo e botar os papos em dia é uma coisa gratificante pra mim. Passar um supervisor, uma pessoa lá de cima e dar bom dia pra mim é gratificante".

- "Eu sou uma pessoa muito comunicativa. Eu gosto muito de conservar, gosto de ver pessoas diferentes, conhecer, fazer amizades. Como agente roda muito e em cada PDV o cara chega, a gente conhece, vai fazendo amizade com um, com outro, é bom demais".

Dejours, Adboucheli e Jayet (1994, p.126) afirmam que "a divisão dos homens solicita, sobretudo, as relações entre as pessoas e mobiliza os investimentos afetivos (...) e a amizade". Neste sentido, conforme observado por Mendes (1999) e por Martins (2002) a relação com os colegas funciona como 
suporte para agüentar o sofrimento do trabalho. A ajuda mútua e o encorajamento por parte dos colegas reduzem o sofrimento e funcionam como estratégia defensiva.

As amizades no ambiente de trabalho também podem ser entendidas como a criação de um espaço público de discussão, onde opiniões podem ser livremente formuladas e publicamente declaradas. Esse espaço possibilita a expressão coletiva do sofrimento (MORRONE, 2001).

A relação de amizade com superiores gera prazer nos trabalhadores, pois é considerada como uma forma de reconhecimento por parte do trabalhador. Essa característica também é evidenciada na categoria B - "Eu acho que sim, sou bastante reconhecido.".

QUADRO 2: Categoria síntese B das entrevistas individuais

"Eu acho que sim, sou bastante reconhecido."

\section{Definição}

O reconhecimento acontece em situações simples, porém de grande significado para os trabalhadores. Os funcionários sentem que são reconhecidos pelos superiores e pelos colegas de trabalho. O reconhecimento verbal é a forma mais comum de reconhecimento. Recompensas materiais são vistas como reconhecimento pela realização de um bom trabalho ou por terem alcançado as metas.

\section{Temas}

- Sente-se reconhecido

- Pequenos gestos significam muito

- Elogios fazem se sentir bem

- Outras empresas não reconheciam tanto

\section{Exemplo de verbalizações:}

- "Eu acho que sim, sou bastante reconhecido. Eu tenho vários elogios, não só na empresa, mas assim, por fora mesmo, de amigos, família, tudo, e... eu sim, acho que sim, sou bem reconhecido".

- "Ah, eu acho que sim. Porque todo mundo aqui gosta de mim. Se eu precisar de alguém aqui é chegar pro supervisor e falar com ele que eles agilizam". 
- "Eu acho que sim. No meu modo de pensar eu sou reconhecido. Chegar alguém e parar pra conversar com você, mostra que aquele chefe ali não tem nada contra você. Se ele veio até você, conversa com você, te trata bem mostra que ele não tem nada contra você, isso é bom".

- "Eu me sinto reconhecido, porque já tive situações que eu saí com produtos da fábrica que na verdade era pra ser carregado de uma forma e foi carregada de outra. Eu cheguei e devolvi o produto pra empresa que não era meu. A empresa foi imediata e me mandou um email, um elogio do meu supervisor, me deu uma gratificação em produto. Isso te da um incentivo pra que você continue".

- "Quando eu chego da rota e encontro meu supervisor, ele vem me cumprimenta e agradece. Veja, ele agradeceu meu serviço, não acha que eu fiz por obrigação. Pra mim isso é gratificante, um bom dia, agradecer pelo que você fez".

- "Reconhece. Eu já trabalhei em outras empresas que não liga muito pro funcionário não. Não dá oportunidade pro funcionário, as vezes o funcionário quer crescer, tem condição de crescer e a empresa não dá oportunidade. Aqui a empresa dá muita oportunidade. A pessoa começa lá embaixo, a empresa vê que o funcionário está se esforçando e dá oportunidade".

Segundo Dejours (1999) a validação social se dá através do reconhecimento. $\mathrm{Na}$ empresa estudada, esse reconhecimento ocorre mais freqüentemente de forma verbal, através de elogios, agradecimentos e da apresentação das melhores equipes do dia anterior.

O reconhecimento do trabalho realizado por parte de colegas e superiores do trabalho realizado contribui para a conquista da identidade do trabalhador, sendo esta dinâmica essencial para ressignificar o sofrimento (ROCHA, 2003).

A categoria indica que o reconhecimento gera prazer no trabalho, contribuindo para a saúde psíquica do trabalhador (MENDES, 1999; MORRONE, 2001).

Por outro lado, conforme indicado por Mendes (1999), o não-reconhecimento do trabalho é fonte de sofrimento, gerando insatisfação e desmotivação nos funcionários. Resultado semelhante é encontrado em trabalhadores do setor bancário por Rocha (2003) e com enfermeiros por Martins (2002). 


\subsection{Fontes de sofrimento}

Em muitos casos o trabalho não cumpre sua função como fonte de prazer, se tornando algo penoso e doloroso, ocasionando o sofrimento no trabalhador. Condições restritivas à plena realização do homem, à sua liberdade, expressão da subjetividade e identidade são fontes de sofrimento (MENDES, 1999).

Dejours (1987) explica que o sofrimento surge quando não é mais possível a negociação entre o sujeito e a realidade imposta pela organização do trabalho.

QUADRO 3: Categoria síntese $C$ das entrevistas individuais

\section{"Tamo sempre no batidão"}

\section{Definição}

A jornada de trabalho dos funcionários começa às sete horas e costuma se estender até as dezessete ou dezenove horas. Há ocasiões em que equipes retornam à empresa depois das vinte horas. $O$ ritmo de trabalho é sempre corrido, não havendo espaço para pausas durante o expediente. Os trabalhadores sofrem pressão interna pelo cumprimento das metas e horários. Existe uma forte divisão entre vida pessoal e vida profissional, horário de trabalho e horário de descanso.

\section{Temas}

- Ritmo de trabalho corrido

- Cansaço constante

- Auto-aceleração

- Pouco tempo pra descanso

\section{Exemplo de verbalizações:}

- "Corrido é. O ritmo é corrido mesmo, bem estressante. Essa área que eu trabalho ali na asa norte é bem estressante. A gente ta ali descarregando chega alguém e pede pro motorista tirar o carro, vai e volta de novo, vai e volta de novo. $\mathrm{O}$ negócio é corrido!"

- "Ah, é muito elevado, muito puxado. Assim, tem que ter muita disposição, porque é um serviço pesado, então não pode desanimar. Se desanimar... porque é muito pesado, é o tipo de serviço, né, que a gente trabalho com cerveja, produtos, é.. pesados, né, então é bem puxado". 
- "Tamo sempre no batidão. É nesse ritmo o dia todo, ou melhor, o mês todo, não pode parar".

- "É acelerado, pesado. Tem as dificuldades no caso que ta muito sol, pra bater carga soa muito. Desce, sobe carga no PDV. Quando ta chovendo, o problema é que você tem que se molhar pra bater a carga".

- "É correria. O ritmo é bem corrido. Se não corrermos não da conta não".

- "Você chega cansado, dia que a gente corre muito né, chega em casa já enfadado e aí já dorme pouco, pra voltar de novo, 6 horas já tem que estar aqui de novo".

- "O trabalho é mais pesado aqui, mas como a gente já ta acostumado com o serviço pesado, não faz tanta diferença".

- "É Cansativo, super cansativo. Pesado pra quem não tem costume. No meu caso eu mexia só com a área de lata, eu vim pra cá mexer com garrafa que eu nunca tinha mexido. Eu acredito que seja uma questão de jeito, quando você pega o jeito, o ritmo do negócio, aí o negócio fica legal".

- "Garrafa é sempre um ritmo pesado, é muito difícil ser leve. A vista dos outros cantos que eu já trabalhei garrafa é pesada. Você faz muito esforço físico, principalmente nas áreas que nem asa norte, asa sul, que só tem escada, quando não é descendo é subindo".

Esta categoria demonstra uma organização do trabalho rígida com elevadas exigências de produtividade. O trabalho também apresenta características de automatização e repetição, visto que há um padrão a ser cumprido em cada entrega com tempo e movimentos determinados.

A categoria indica sofrimento no trabalho, cujas fontes são a pressão pelo cumprimento das entregas, a correria do expediente e a necessidade de acelerar as cadências de trabalho (ROCHA, 2003).

O esforço físico também é uma característica marcante da organização do trabalho de distribuição de bebidas. Os funcionários lidam diariamente com cargas que podem ultrapassar os cinqüenta quilogramas. Devido ao esforço físico constante é comum a ocorrência de lesões e problemas decorrentes da atividade realizada.

QUADRO 4: Categoria síntese D das entrevistas individuais

“Eles querem que a gente chegue cedo, mas põem um monte de entrega."

\section{Definição}


As atividades a serem desempenhadas são altamente padronizadas. Em nome da produtividade as necessidades dos trabalhadores são sacrificadas. É comum ser atribuído um número excessivo de entregas para a equipe de distribuição. Em dias puxados os trabalhadores chegam a ficar sem almoçar para garantir o cumprimento das entregas. $O$ excesso de atividades gera desanimo nos funcionários. É preciso estar o tempo todo atento aos detalhes, pois qualquer deslize é cobrado da equipe.

Cada membro da equipe sabe claramente qual o seu papel durante a entrega. Os motoristas lidam com a pressão interna por se sentirem responsáveis pela vida dos colegas.

\section{Temas}

- Excesso de atividades

- Pressão por resultados

- Cobrança pelo erro zero

\section{Exemplo de verbalizações:}

- "A sensação assim é bem... bem puxado, né? Porque, poxa, as vezes sai com um caminhão assim bem carregado mesmo, meio-dia, e a gente fez uma entrega, aí a gente quando vai olhar tem mais umas 4 entrega, o caminhão tá pelo meio ainda, aí as vezes bate uma sensação meia bruta, né? Mas, da um desânimo as vezes".

- "Sair com as entregas bem localizada, porque tem dia que as entregas sai tudo espalhada, tem aqui, final da asa norte, aí tem que correr muito pra chegar".

- "Sair de casa tranqüilo, sabendo que você tem que trabalhar, vai lidar com pessoas. Além de tudo você carrega duas vidas do seu lado, a nossa também e a do próximo que ta no dia-a-dia. Você ta sujeito a qualquer tipo de situação, você ta dirigindo um carro, uma máquina".

- "O ritmo de trabalho é pesado, é corrido. Se a pessoa pega 45 notas que nem hoje é difícil".

- "Geralmente saímos com 40 entregas pra uma rota como o Gama que é grande, setor sul, norte e oeste, além disso tem cliente que temos que passar duas vezes porque tá fechado, ou então cliente que tá sem dinheiro e pede pra voltar mais tarde. Aí tem que ficar voltando neles pra zerar a carga".

- "Só que não sei como é isso não. Eles querem que a gente chegue cedo, mas põem um monte de entrega. Aí fica uma correria danada. Tem que correr demais pra tentar chegar no horário. Tem dia que a gente nem almoça".

- "É pra bater as metas, né? Pra chegar zerado, pra não devolver, fazer as entregas direitinho." 
- "Nosso objetivo é zerar a carga. Zerar a carga pra ficar bonito."

Dejours (1994) identifica a diferença entre a organização de trabalho prescrita e a real. A primeira é aquela imposta pelo empregador, enquanto a segunda consiste na atualização, feita pelo trabalhador, do trabalho prescrito para viabilizar a execução das atividades.

$\mathrm{Na}$ empresa estudada, a organização do trabalho prescrita prevê papéis claramente divididos entre motoristas e ajudantes, cada qual com suas atribuições estabelecidas. Entretanto, para viabilizar a melhor execução das atividades no dia-adia, os funcionários costumam transgredir as regras estabelecidas, alternando os papéis entre a equipe de forma a ganhar agilidade e produtividade. Essa estratégia defensiva é apresentada por Dejours (1999) como um mecanismo utilizado pelo trabalhador para melhorar a produção e assim diminuir suas chances de ser demitido.

Tanto na categoria C - "Tamo sempre no batidão" - quanto na categoria D "Eles querem que a gente chegue cedo, mas põem um monte de entrega." - os participantes demonstraram a exigência de cumprir metas e atender à sobrecarga de trabalho, mesmo quando as exigências são incongruentes com as necessidades dos trabalhadores.

Nesse contexto, os funcionários utilizaram-se da estratégia de aceleração das cadências como forma de diminuir a pressão interna por alcance das metas e pelo status que isto promove, e também a pressão externa por produtividade e pelo cumprimento das atribuições. Martins (2002) e Rocha (2003) apresentam resultados similares com outras categorias de trabalhadores.

QUADRO 5: Categoria síntese E das entrevistas individuais

\section{"Todo mundo pensa que garrafeiro é ladrão."}

\section{Definição}

O relacionamento com os clientes costuma ser de amizade, embora ocorram problemas com alguns clientes. Mesmo em casos em que não é responsável pela situação, a equipe é vista sempre como a culpada. Erros de montagem de carga, problemas de fabricação e problemas causados por falta de atenção no descarregamento dos produtos fazem com que a equipe de distribuição seja mal 
vista e em alguns casos acusada verbalmente por clientes. Há relatos de clientes que ameaçaram de morte membros da equipe de distribuição.

\section{Temas}

- Violência por parte dos clientes

- Desgaste no relacionamento com clientes

- Fui acusado de roubo

\section{Exemplo de verbalizações:}

- "as vezes cliente, né? Porque o cliente as vezes ta com um problema, as vezes a gente chega, não tem nada a ver, mas ele já tá sobrecarregado lá e já vem logo descontando na gente. Então as vezes é um pouco assim meio desagradável a questão de clientes, né?"

- "Alguns clientes chatos. Mexer com gente você sabe que é um problema. Tem cliente que acha você maravilhoso, (...) mas sempre tem 1 cliente que é o mais chato, mais te perturba e ainda não gosta de você, tudo que você faz pra ele ta ruim".

- "Algumas vezes existem umas dificuldades, falta um produto por exemplo e o cliente quer receber e causa uma polêmica com o motorista que na verdade não tem nada a ver com a situação".

- "Uma outra dificuldade grande foi quando um cliente nos chamou de ladrão. Foi provado que a gente não tinha nada a ver, pelos supervisores e pelas leis em geral. Todo mundo pensa que garrafeiro é ladrão. Essa é a dificuldade nossa maior".

- "Tem muito cliente que é problemático, tem horário pra receber, tem os detalhes de cliente".

O relacionamento com os clientes, quando ocorre de forma satisfatória, gera prazer no trabalhador, pois este se sente reconhecido. Contudo é comum a ocorrência de situações de tensão entre clientes e funcionários. A relação com os clientes demonstra um caráter paradoxal por ser o cliente também fonte de sofrimento ao estabelecer uma relação de pressão ou violência (MORRONE, 2001).

Dejours (1999) expõe que a relação direta com clientes, característica presente no trabalho de distribuição de bebidas, dificulta a expressão de agressividade por parte do trabalhador aumentando a supressão dos pensamentos de teor agressivo. Esta característica da organização do trabalho limita a 
possibilidade de expressão dos trabalhadores, configurando-se como fator de sofrimento no trabalho.

Dejours (1999) apresenta ainda o conceito do julgamento da utilidade técnica, social ou econômica realizado por chefes, pares e pelos clientes. Caso o julgamento ocorra de forma positiva pode ser fonte de prazer para o trabalhador. Para que a sua utilidade seja reconhecida o trabalhador recorre a estratégia de aceleração das cadências, de forma a tentar garantir a satisfação do cliente as custas de suas limitações físicas.

O medo de sofrer violência ou de serem acusados por clientes suscita em pressão nos trabalhadores que buscam redobrar a atenção na execução das atividades visando minimizar a ocorrência de erros que possam evoluir em situações de conflito com clientes.

\subsection{Sentido e significados do trabalho}

Desde os primórdios da civilização o trabalho faz parte da condição humana, influenciando a forma de construção das sociedades e dos homens ao longo da história (MENDES, 1999). Nesse contexto, foi analisada a percepção dos trabalhadores sobre o sentido e o significado do trabalho para cada indivíduo, observando qual o papel ocupado pelo trabalho em suas vidas e como eles se sentem em relação ao mesmo.

QUADRO 6: Categoria síntese F das entrevistas individuais

\section{“...a pessoa sem trabalho não tem nada na vida."}

\section{Definição}

O trabalho é parte da identidade social dos trabalhadores. O trabalho é visto como uma parte de si mesmo. Não estar trabalhando é considerado entediante e frustrante. A vida dos funcionários gira em torno do trabalho, para muitos o trabalho é tudo, pois sem trabalho eles não seriam nada. $O$ trabalho é fonte de renda e possibilita alcançar os sonhos e objetivos pessoais. O trabalho é motivo de orgulho, gostam do que fazem e por isso são felizes. 


\section{Temas}

- Sente orgulho do trabalho

- Trabalho fonte de sustento

- Vê o trabalho como sua vida

\section{Exemplo de verbalizações:}

- "Ah, significa uma honra pra mim, né? O trabalho é assim, a dignidade, né, pro homem, o trabalho. Poxa, você trabalhar, mostrar o seu serviço, o que você sabe fazer, é gratificante, né, também, você, assim, mostrar pras outras pessoas que você, poxa, você trabalha, que você sabe fazer um negocio..."

- "Eu venho pra cá tranqüilo, venho feliz. Mesmo sendo meu trabalho, pra mim é uma coisa gratificante. Porque é o que eu gosto de fazer. Mesmo eu dependendo de dinheiro e essas coisas, é uma boa. Eu fico muito satisfeito de estar vindo trabalhar. Eu acho muito legal. Pra mim é melhor do que ficar em casa, olhando pra cara de um, cara de outro, escutando uma conversa aqui, outra ali. É gosto vir trabalhar".

- "Eu preciso do meu trabalho hoje em dia. É saber que eu tenho que fazer o meu pra que eu possa sobreviver."

- "É tudo, significa tudo. Eu faço por onde estar todos os dias dentro do meu horário, sem falta, sem reclamações, sem nada. Porque meu trabalho pra mim é tudo. Eu trabalho não é pra ninguém me ver não, é pra eu mim mesmo, pra me sentir a vontade. Trabalhar certo, honestamente".

- "Eu digo que quase tudo, quase tudo na minha vida. Porque a pessoa sem trabalho não tem nada na vida. Se você não tem trabalho de você vai tirar seu sustento? De onde você vai vestir ou tirar a educação dos seus filhos? Pra mim é quase tudo, é uma parte minha já".

- "Eu gosto do que eu faço, eu gosto muito do que eu faço. Eu não tenho muito do que reclamar não. Porque o serviço depende muito da gente. Se a pessoa faz uma coisa que a gente gosta, então tudo da certo. Agora se a pessoa faz uma coisa que a pessoa não gosta, tudo da errado. Então pra mim é uma ótima ocasião".

- "Eu sinto orgulho e me sinto um vencedor. Quando eu cheguei em Brasília cheguei só com o cachorrinho nas costas. Já tenho minha casa, se quiser um carro de pelo menos uns 20 mil já posso comprar, então tamos aí na batalha."

- "Sinto muito orgulho. É uma profissão digna. É igual eu falo, você fazer as coisas que gosta. Eu gosto de dirigir caminhão, dirijo desde pequeno, meu pai tinha caminhão e desde pequeno eu dirigia. É minha paixão. " 
O trabalho atende primeiramente à necessidade básica de segurança dos trabalhadores, pois fornece uma fonte de sustento e de sobrevivência. Nesse sentido, o trabalho é visto como meio de subsistência, podendo ser considerado um mal necessário (MENDES, 1999).

Entretanto, Dejours (1999) ressalta que o trabalho não pode ser visto apenas como atividade. $O$ trabalho também é realização e identidade. Estar produzindo faz com que o indivíduo se sinta valorizado e reconhecido pelo que faz. O trabalho passa então a atender a necessidade de auto-realização do trabalhador (MENDES, 1999).

Os trabalhadores apresentaram motivação em realizar suas atividades, considerando o trabalho como motivo de orgulho e como fonte de satisfação. A garantia do sustento que 0 trabalho proporciona e o gosto pelas atividades demonstra que o trabalho é visto como um aspecto positivo na vida dos entrevistados. 


\section{CONCLUSÃO E RECOMENDAÇÕES}

Este estudo foi realizado com o objetivo de analisar as vivências de prazer e sofrimento no trabalho de distribuição de bebidas, tendo enfoque nas fontes de prazer e sofrimento, bem como nas características da organização do trabalho.

Os resultados obtidos, demonstrados e discutidos nos capítulos anteriores permitem a obtenção de conclusões gerais para a categoria de trabalhadores pesquisados, que serão apresentadas a seguir.

A organização do trabalho de distribuição de bebidas é marcada pela divisão de tarefas claras e bem definidas entre a equipe, com atribuições específicas definidas para motoristas e ajudantes. É comum entre os trabalhadores a transgressão das normas escritas com objetivo de aumentar a produtividade e melhorar a realização do serviço

O trabalho é tido como fonte de prazer, pois possibilita uma identificação dos trabalhadores com as atividades executadas. As amizades no trabalho permitem a expressão pública e o compartilhamento do sofrimento no ambiente de trabalho.

O reconhecimento vivenciado pelos trabalhadores é fonte de prazer para estes, pois aumenta sua auto-estima e faz com que eles se sintam valorizados perante os superiores e frente aos pares. Os mecanismos de reconhecimento mais eficazes são aqueles que ocorrem através de gestos simples como saudações e cumprimentos.

Por outro lado, o trabalho também apresenta aspectos causadores de sofrimento. Entre eles está o ritmo acelerado de trabalho que impossibilita $O$ descanso dos trabalhadores, explorando os trabalhadores até seu limite físico. A organização do trabalho também gera automatização e repetição constantes, além de expor os trabalhadores a pressões externas e internas. 
O esforço físico constante, ausência de períodos de descanso e o ritmo acelerado de trabalho provocam o adoecimento dos trabalhadores e ocasionalmente resultam em lesões e problemas de saúde diversos.

O relacionamento com clientes apresenta-se com um caráter paradoxal. Por um lado, ele é fonte de prazer através do reconhecimento pelo bom trabalho, enquanto por outro gera sofrimento devido às ameaças de violência e à pressão exercida.

Para lidar com as pressões do trabalho, a resposta mais utilizada pelos funcionários é aceleração das cadências, não somente devido às pressões sofridas, mas porque os trabalhadores interiorizam os objetivos da empresa. Esta estratégia de defesa é valorizada pelos superiores e clientes, mas evita a identificação do sofrimento, gerando alienação, adequação à situação e manutenção da mesma.

Quanto ao sentido e ao significado os resultados demonstraram que o trabalho é motivo de orgulho para os funcionários, visto que há uma identificação com a função exercida e o gosto pela profissão. $O$ trabalho também é visto como fonte de identificação pessoal, visto que estar desempregado é considerado como degradante pelos trabalhadores.

A realização deste estudo traz contribuições relevantes por demonstrar empiricamente constructos teóricos, por confirmar resultados que vem sendo obtidos por diversos pesquisadores e ainda por apontar conclusões que ampliam o conhecimento da área.

Não obstante, não se pode deixar de tecer algumas considerações sobre as limitações do presente estudo. Ele foi realizado com trabalhadores do setor de distribuição de uma única empresa. Seria interessante a realização de comparações com trabalhadores do setor de distribuição de diversas empresas, na expectativa de consolidar algumas conclusões e buscar especificidades das empresas estudadas.

Recomenda-se também a realização de estudos mais detalhados sobre o trabalho de distribuição de bebidas diferenciando as vivências de prazer-sofrimento entre motoristas e ajudantes. 


\section{REFERÊNCIAS}

BARDIN, L. Análise de conteúdo. Lisboa: Edições 70, 1977.

BLEGER, J. Temas de psicologia: entrevistas e grupos. São Paulo: Martins Fontes, 1991.

DEJOURS, C. A loucura do trabalho: estudo de psicopatologia do trabalho. São Paulo: Cortez, 1987.

DEJOURS, C. A carga psíquica do trabalho. In: Dejours, C.; Abdoucheli, E.;; Jayet, C. Psicodinâmica do Trabalho: Contribuições da escola Dejouriana à análise da relação prazer, sofrimento e trabalho. São Paulo: Atlas, 1994.

DEJOURS, Christophe. A banalização da injustiça social. Rio de Janeiro: FGV, 1999.

FOUCAULT, Michel. Vigiar e punir: Nascimento da prisao. 15. ed. Petropolis: Editora Vozes Ltda, 1997. 276 p.

FREITAS, M. E. Contexto Social e Imaginário Organizacional Moderno São Paulo: RAE - Revista de Administração de Empresas, v.40, n.2, p. 6-15, 2000.

GAULEJAC, V. Gestão como doença Social: ideologia, poder gerencialista e fragmentação social. São Paulo: Idéias \& Letras, 2007.

GODOY, A. Introdução à pesquisa qualitativa e suas possibilidades. São Paulo: RAE - Revista de Administração de Empresas, v. 35, n.2, p. 57-63, 1995.

LAVILLE, C.; DIONNE J. A construção do saber: manual de metodologia da pesquisa em ciências humanas. Porto Alegre: Ed. Artmed, 1999. 344p. 
MARTINS, J. T. Prazer e sofrimento no trabalho do enfermeiro em Unidades de Terapia Intensiva: estratégias defensivas. Tese de Doutorado, Escola de Enfermagem da Universidade de São Paulo, Ribeirão Preto, 2002.

MORGAN, G. Imagens da Organização. São Paulo: Atlas, 2007.

MORRONE, C. F. "Só pra não ficar desempregado". Ressignificando o sofrimento psíquico no trabalho: estudo com trabalhadores em atividades informais. Dissertação de Mestrado, Universidade de Brasília, Brasília, 2001.

MENDES, A. M. Psicodinâmica do Trabalho: teoria, método e pesquisas. São Paulo: Casa do Psicólogo, 2007.

MENDES, A. M. Valores e vivências de prazer-sofrimento no contexto organizacional. Dissertação de Mestrado, Universidade de Brasília, Brasília, 1999.

RICHARDSON, R. J. Pesquisa Social: método e técnicas. São Paulo: Atlas, 1999.

ROCHA, S.R.A. "O pior é não ter mais profissão, bate uma tristeza profunda": sofrimento, distúrbios osteomusculares relacionados ao trabalho e depressão em bancários. Dissertação de mestrado, Universidade de Brasília, 2003.

SIQUEIRA, M. Gestão de pessoas e discurso organizacional. Curitiba: Juará, 2009.

VERGARA, S. C. Projetos e relatórios de pesquisa em administração. São Paulo: Atlas, 2005. 


\section{APÊNDICES}

\section{APÊNDICE A}

\section{Roteiro de Entrevista}

1) Conte-me sobre sua trajetória profissional.
a) Há quanto tempo está na função atual
b) Onde trabalhou anteriormente?
c) Quais atividades eram realizadas

2) Fale-me sobre o trabalho de motorista/ajudante.
a) Descreva as atividades que você realiza
b) Comente sobre as relações com a chefia
c) Como é o ritmo de trabalho? Existe cobrança por resultados?
d) Fale sobre a abertura a idéias e o fluxo de comunicação

3) Que sentimentos você vivencia em relação ao trabalho?
a) O que você pensa quando está a caminho do trabalho?
b) Ao longo do dia, o que você pensa sobre o trabalho?
c) No fim do dia, quais sentimentos você vivencia?

4) Quais dificuldades você enfrenta no trabalho?
a) Quais são os obstáculos enfrentados no dia-a-dia?
b) $O$ que the causa frustração em relação ao trabalho?

5) Como você faz para lidar com o dia-a-dia de trabalho?
a) O que você faz fora do trabalho?
b) Como você lida com a pressão do dia-a-dia?

6) O que o seu trabalho significa pra você? Você se sente motivado em relação a ele?
a) Você sente orgulho pelo que faz?
b) Qual é o papel do trabalho na sua vida?
c) Você se considera reconhecido pelo trabalho que realiza?
d) Qual a sua visão sobre os mecanismos de reconhecimento do trabalho? 